\title{
Maria Grotowska
}

\section{Problematyka wyrażenia świadomej zgody w aspekcie wykorzystywania płodów}

\begin{abstract}
W artykule poruszona została kwestia wyrażania zgody w przypadku wykorzystywania tkanek oraz komórek macierzystych znajdujących się w martwych płodach. Analiza dotyka problemu tyle istotnego, ze względu na możliwości zastosowania tkanek w leczeniu licznych schorzeń, co kontrowersyjnego, z powodu spornego stanowiska odnośnie do przerywania ciąży przez kobiety oraz sposobu ich pozyskiwania dla celów badawczych, a także obowiązku uzyskania zgody przez uczestnika w eksperymencie medycznym.
\end{abstract}

\section{Wstęp}

Spory dotyczące pozyskiwania i wykorzystywania komórek macierzystych na płaszczyźnie prawnej, etycznej i społecznej rozgorzały w 1989 r., kiedy pierwszy raz doszło do ich uzyskania w laboratorium. Odkrycie to wywołało liczne kontrowersje, które spowolniły proces rozwoju i ukształtowały wiele aspektów tej dziedziny nauki ${ }^{1}$. Niewątpliwie badania nad komórkami macierzystymi zaliczają się do kategorii eksperymentów medycznych, wywołujących zarówno wiele pozytywnych, jak i negatywnych reakcji, co wynika ze sposobu ich pozyskiwania.

\section{Problem pozyskiwania komórek macierzystych znajdujących się w martwych} plodach

Komórki macierzyste są istotne przez wzgląd na swoją zdolność do samoodnowy, co przejawia się w utrzymaniu homeostazy ustroju oraz możliwości regeneracji tkanek, choćby w możliwości naprawy komórek wątroby po częściowej hepatektomii. Wyróżnia je to, że w przeciwieństwie do innych komórek, mogą być pluripotencjalne oraz totipotencjalne, co generalnie oznacza, że mogą ulec przekształceniu w niemalże każdy narząd ludzki ${ }^{2}$. Medycyna wiąże znaczne nadzieje na ich wykorzystanie w celach terapeutycznych wielu

\footnotetext{
${ }^{1}$ J. A. Robertson, Embryo Stem Cell Research: Ten Years of Controversy, Journal of Law, Medicine \& Ethics, vol. 38, s. 191.

${ }^{2}$ H. Bartel, Embriologia, Warszawa 2010, s. 544-553.
} 
chorób. Źródłem komórek macierzystych są między innymi gonady martwych płodów posiadające komórki EG. W tym przypadku nie istnieje problem etyczny w postaci pozyskiwania tego typu komórek, skoro płód jest już martwy, w związku z czym nie następuje poświęcenie żadnego zarodka ludzkiego w celu badań nad nim bądź przysłużenia się innym ${ }^{3}$.

Ten cenny materiał można także pozyskać w wyniku naturalnego poronienia, ale to nieliczne przypadki. Częściej tego typu komórki otrzymuje się w wyniku dokonanej aborcji. Powszechnie wiadomo, że jest to temat dość sporny oraz kontrowersyjny, nawet jeśli zabieg został dopuszczony przez regulacje prawne danego kraju. Obiekcje podnoszone podczas dyskusji na temat jej dopuszczalności mogą wpływać na postrzeganie kwestii wykorzystywania komórek w celach medycznych ${ }^{4}$. Podobnie, choć znacznie bardziej rozlegle, przedstawia się problematyka uzyskiwania komórek przeznaczonych do badań z zapłodnionych embrionów, które również mogą posłużyć do rozwiązania wielu schorzeń, choćby choroby Alzheimera ${ }^{5}$ czy Parkinsona ${ }^{6}$.

Przeciwnicy zdobywania komórek pluripotencjalnych z gonad martwych płodów przedstawiają dwa podstawowe zarzuty. Pierwszy z nich to argument $\mathbf{z}$ niemożliwości uzyskania ważnej zgody, który odnosi się do kwestii wydania świadomej zgody w celu prowadzenia badań. Zgodnie $\mathrm{z}$ większością regulacji na świecie, aby przeprowadzać jakiekolwiek badania należy uzyskać uprzednio ważną oraz świadomą zgodę na tego typu eksperyment. W polskim ustawodawstwie kwestie te reguluje Konstytucja ${ }^{7}$, Kodeks karny ${ }^{8}$, ustawa o zawodach lekarza i lekarza dentysty ${ }^{9}$ oraz Kodeks Etyki Lekarskiej. W art. 73 Konstytucji przewidziana została swoboda badań naukowych, ograniczona w art. 39, w którym zakazano doświadczeń bez zgody uczestnika. Zgodnie ze stanowiskiem Trybunału Konstytucyjnego niedopuszczalne są badania medyczne bez zgody probanta, gdyż narusza to zasady demokratycznego państwa ${ }^{10}$. Kodeks karny w art. $27 \S 1$ odnosi się do szerokiego katalogu eksperymentów, w tym medycznego, jednocześnie wskazując w $\S 2$, że nie jest on dopuszczalny bez zgody uczestnika, poinformowanego o przewidywanych

\footnotetext{
${ }^{3}$ W. Galewicz, Status ludzkiego zarodka a etyka badań biomedycznych, Kraków 2013, s. 231-240.

${ }^{4}$ Ibidem

${ }^{5}$ M. De Silva, Alzheimer's disease: how could stem cells help?, http://www.eurostemcell.org/alzheimersdisease-how-could-stem-cells-help [dostęp 25.9.2017 r.]

${ }^{6} \mathrm{~S}$. Halliday, A Comparative approach to the regulation of human embryonic stem cell research in Europe, Medical Law Review 2004, nr 12, s. 40

${ }^{7}$ Konstytucja Rzeczypospolitej Polskiej z 2.4.1997 r., Dz. U. z 1997 r. Nr 78, poz. 483 z późn. zm.

${ }^{8}$ Ustawa z 6.6.1997 r. - Kodeks karny, t.j. Dz.U. z 2016 r. poz. 1137 z późn. zm., dalej jako k.k.

${ }^{9}$ Ustawa z 5.12.1996 r., t. j. Dz.U. z 2017 r. poz. 125 z późn. zm.

${ }^{10}$ Uchwała Trybunału Konstytucyjnego z 17.3.1993 r. sygn. akt W 16/92, OTK 1993, nr 1, poz. 16.
} 
korzyściach oraz negatywnych skutkach, w tym prawdopodobieństwie ich postania oraz możliwości odstąpienia od udziału w eksperymencie na każdym jego etapie. Podobne regulacje zostały zawarte w ustawie o zawodach lekarza i lekarza dentysty, z dodatkowym wyszczególnieniem, że dziecko poczęte nie może uczestniczyć w eksperymencie badawczym (art. 26 ust. 3 ustawy). Użyte sformułowanie jest pojęciem nieostrym, stąd nie ma pewności jak szeroki ma zakres i czy dotyczy również gonad martwych płodów. Nie jest jasne, kto ma wyrazić zgodę na przekazanie komórek do badań ${ }^{11}$. Pierwszą osobą, która przychodzi na myśl, jest matka, czyli kobieta, która usunęła ciążę bądź poroniła. Budzi to jednak pewne wątpliwości, ponieważ uznać można, że skoro zdecydowała się na przerwanie ciąży, to zrzekła się prawa do rozporządzania szczątkami płodu, a jednocześnie los jej dziecka może być dla niej obojętny ${ }^{12}$.

Kolejny argument wysuwany przez krytyków wykorzystywania komórek to argument współuczestnictwa w złu. Wywodzi się z założenia, że skoro aborcja należy do kontrowersyjnych działań o wątpliwie moralnym podłożu, a w wielu przypadkach bywa określana jako niepoprawna, to korzystający $\mathrm{z}$ nich badacze, mają przez to pewien współudział w tych zabiegach, ponieważ czerpią z nich korzyści ${ }^{13}$.

W artykule omówiony zostanie argument dotyczący wyrażenia świadomej zgody.

\section{Argument braku ważnej zgody pobierania tkanek i komórek}

James Burtchaell i Kathleen Nolan jako pierwsi sformułowali argument braku ważnej zgody przy wykorzystywaniu resztek poaborcyjnych do badań. J. Burtchaell w swoim sporze z Robertsonem oraz Freedmanem twierdził, że matka nie ma prawa do rozporządzania szczątkami poaborcyjnymi dziecka, ponieważ podjęta przez nią decyzja o przerwaniu ciąży dyskwalifikuje ją jako osobę darzącą płód jakąkolwiek opieką. Swój wniosek opiera na twierdzeniu, że matka czy jakakolwiek osoba, która jest stroną w tej sytuacji, tj. ojciec, położnik czy państwo, nie ma prawa do podejmowania tego typu decyzji, ponieważ matka podjęła decyzję o dokonaniu aborcji, ginekolog położnik brał w tym udział, partner matki W żaden sposób jej nie powstrzymał bądź aprobował jej działania, a państwo na to pozwoliło,

\footnotetext{
${ }^{11}$ W. Galewicz, Antologia bioetyki, Kraków 2011, s.16-25

${ }^{12}$ W. Galewicz, Status..., s. 232

${ }^{13}$ Ibidem.
} 
W związku z tym żadna z wyżej wymienionych osób nie posiada moralnego autorytetu do podejmowania decyzji w imieniu zmarłego, czyli usuniętego płodu ${ }^{14}$.

Natomiast K. Nolan w swoim artykule „Genung ist genung. A fetus is not a kidney”, stoi na stanowisku, że kobieta może oddać płód do badań, tylko jeśli sama nie przyczyniła się do jego śmierci, czyli wyłącznie w wypadku naturalnego poronienia, a nie aborcji. Autorka podkreśla, że jeżeli mamy do czynienia z takim przypadkiem, wówczas taka kobieta nie różni się od zwykłego krewnego, który stracił bliską osobę ${ }^{15}$. Natomiast odnośnie do matki, która zdecydowała się przerwać ciążę, wątpliwe jest czy może nawet rościć sobie prawa do tytułu matki, a tym bardziej udzielać zgody na pobranie komórek macierzystych $\mathrm{z}$ martwego płodu.

Jak słusznie zauważa W. Galewicz, nie jest określony zakres podnoszonego argumentu przeciwko wykorzystywaniu komórek macierzystych z martwych płodów. Tylko jeśli aborcja jest dopuszczona przez przepisy prawne istnieje problem wyrażenia świadomej zgody za usunięty płód, dlatego logicznie rozumując, argument ten powinien się odnosić do takiej sytuacji ${ }^{16}$. K. Nolan obala to ograniczenie uznając: „Przyczyniać się do śmierci innej osoby znaczy ostatecznie uprzedmiotawiać tę drugą osobę, używać jej do celów, które nie są jej własnymi celami. Tak zatem nawet jeśli ktoś uważa, że aborcja z wyboru może być etycznie usprawiedliwiona (bądź to w ogóle, bądź to w szczególnych przypadkach), to jednak zgoda matki, a nawet zgoda społeczeństwa na wykorzystanie szczątków płodu (do celów badawczych) budzi wątpliwości” ${ }^{17}$. Z powyższego jasno wynika, że matka nie powinna być decydentem w przypadku usunięcia płodu, ponieważ przyczyniła się do jego śmierci. Aby lepiej zrozumieć ten argument, warto go przedstawić na zasadzie rozumowania logicznego:

1) Potrzebna jest ważna zgoda osoby uprawnionej bądź strony aby można było przeprowadzić badania $\mathrm{z}$ tkanek martwych płodów tak, żeby nie wzbudzało to poczucia niemoralności.

2) W przypadku płodu poaborcyjnego nie ma osoby uprawnionej bądź strony, która mogłaby podjąć taką decyzję, ponieważ matka sama przyczyniła się do jej dokonania, a pozostałe strony też nie są moralnie upoważnione do rozporządzania szczątkami.

\footnotetext{
${ }^{14}$ J. T. Burtchaell, The Use of Aborted Fetal Tissue in Research: A Rebuttal, A Review of Human Subjects Research 1989, vol. 11, Nb 2, s. 9-12.

${ }^{15}$ K. Nolan, Genug ist Genug: A Fetus Is Not a Kidney, Hastings Center Report 1988, vol. 18, Nb 6, s. 13-19.

${ }^{16}$ W. Galewicz, Status..., s. 232.

${ }^{17}$ K. Nolan, op.cit, s. 13-19.
} 
Wniosek: Skoro nie ma osoby, która mogłaby wyrazić ważną, świadomą zgodę na przeprowadzenie takich badań, to takie badania nigdy nie będą moralnie usprawiedliwione $^{18}$.

Opozycjoniści tego argumentu, czyli w głównej mierze John A. Robertson oraz Benjamin Freedman, podważają ten logiczny ciąg rozumowania, a w szczególności drugą przesłankę. J.A. Robertson zgadza się, że być może ta kobieta nie jest osobą najwłaściwszą, jednak podkreśla: „osoba rozporządzająca szczątkami nie jest opiekunem ani reprezentantem osoby zmarłej, bo ta nie posiada interesów, które ktoś mógłby chronić. Właściwiej byłoby określić ich rolę jako opiekunów własnych uczuć i interesów, ponieważ chcą zadbać o to, aby szczątki zmarłego były traktowane z należytym szacunkiem, a nie o to, by spełniona została wyrażona przez nich za życia wola (...). Dlatego fakt, że kobieta, która czyni użytek ze swojego prawa do aborcji, nie stoi na przeszkodzie czy nie przeszkadza żadnemu z celów, jakie bierze się pod uwagę, przyznając najbliższym krewnym możliwość podejmowania decyzji o wykorzystaniu ludzkich szczątków do badań, terapii, czy innych celów"19. Podobnie twierdzi B. Freedman, uznając, że zgoda przerywającej ciążę nie jest daniem upoważnienia, ale jedynie wyrazem nastroju, który musi być uszanowany, ponieważ jest jedną z tych, mających coś do powiedzenia odnośnie tej decyzji. Jednym słowem, są to jej korzyści, a nie potomka, które wchodzą w grę ${ }^{20}$.

Jednakże w ślad za Wł. Galewiczem uznać należy, że w tych tezach jest coś niewystarczającego, skoro podważają także pierwszą przesłankę, na której opierają się przeciwnicy wykorzystywania komórek martwych płodów. J.A. Robertson przyznaje, że jeżeli chcemy uczynić użytek ze szczątków poaborcyjnych, to istnieją powody, aby starać się o zgodę krewnych, jednakże nie jest jasne, czy ich świadoma zgoda jest bezwzględna ${ }^{21}$. Wynika to $\mathrm{z}$ jego stanowiska odnoszącego się do istotności celu używania zwłok: jeśli ten użytek jest godziwy, wtedy zgoda może być pożądana, ale nie zawsze jest niezbędna. Powołuje się na przykład sekcji zwłok dla celów naukowych bądź z powodów prawnych. Nie jest ona niegodziwa, nawet jeżeli krewni nie wyrazili uprzedniej zgody. Podnosi, że w dwunastu stanach USA możliwe jest pobranie rogówek od zmarłych, pomimo braku ich zgody, a nie uważa się tego za niegodziwe. Skoro zatem pobieranie narządów

\footnotetext{
${ }^{18}$ W. Galewicz, Status..., s. 233.

${ }^{19}$ J.A. Robertson, Fetal Tissue Transplant Research is Ethical, IRB 1998, nr 10, s. 5-8.

${ }^{20}$ B. Freedman, The Ethics of Using Human Fetal Tissue, IRB 1998, nr 10, s. 1-4.

${ }^{21}$ W. Galewicz, Status..., s. 234-235.
} 
i tkanek ze zwłok nie jest naganne, tak samo powinno być w przypadku martwych płodów, jeżeli są używane w tym samym celu ${ }^{22}$.

Przeciwnikiem ostatniego twierdzenia J.A. Robertsona jest C. Strong. Drugi z autorów podnosi, że nie ma pewności, czy stosowane praktyki w stosunku do zwłok - w razie braku zgody krewnych - są rzeczywiście godne aprobaty. Wskazuje, że z wyjątkiem prokuratorskich przypadków, amerykańskie prawo wymaga, aby autopsja była uprzednio poparta przez najbliższych, a lekarz, który przeprowadziłby ją bez ich zgody, może zostać pociągnięty do odpowiedzialności z tego tytułu. C. Strong przyznaje, że choć istnieją przypadki, gdy taka zgoda nie jest respektowana, dotyczą one szczególnych sytuacji, np. chorób zakaźnych i nie świadczą o przestrzeganiu zasady poszanowania, a jedynie o tym, że występują okoliczności stwarzające jej przeciwwagę, np. kwestia zdrowia publicznego. Podobnie przez wzgląd na pewne regulacje prawne jest, zdaniem Autora, z pobieraniem rogówek czy przeprowadzaniem autopsji, co uzasadnia tezę, że wszystkie działania w stosunku do szczątków można usprawiedliwiać uznając, że uszczerbek na ich godności jest mały w porównaniu do profitów, które przysługują żyjącym²3.

Trudno zająć stanowisko w tym sporze. Niewątpliwie trafnie stwierdza B. Freedman, że matka powinna mieć wpływ na decyzje podejmowane wobec jej dziecka, ponieważ nawet formalnie jest jego spadkobiercą. To, że przyczyniła się do usunięcia płodu nie powinno jej dyskwalifikować. Przyjmując nawet personalny charakter płodu, czyli uznawszy go za człowieka posiadającego takie sama prawa jak dorosły osobnik, w przypadku jego zgonu, decyzję podejmować będą rodzice bądź sama matka. W związku z tym to oni będą wyrażali zgodę na pobranie komórek bądź tkanek z martwego płodu. Taka sama sytuacja występuje w przypadku śmierci klinicznej kilkuletniego dziecka. To rodzice mają możliwość rozporządzania jego ciałem, przekazaniem zdatnych narządów do przeszczepu bądź badań. Należy także również pamiętać o wewnątrzmacicznym obumieraniu płodu, które choć zdarza się rzadko, daje możliwość by otrzymane w ten sposób tkanki posłużyły do dalszych badań ${ }^{24}$. Warto również zwrócić uwagę na rozwiązanie zastosowane przez Uniwersytet Wisconsin. Dopuszczono tam możliwość przeprowadzania badań przez uniwersyteckich naukowców z wykorzystaniem tkanki ludzkiego płodu, a jako decydenta wskazano matkę, która musi wyrazić pisemną zgodę na wykorzystanie materiału płodu dla celów terapeutycznych,

\footnotetext{
${ }^{22}$ J.A. Robertson, Fetal..., s. 8.

${ }^{23}$ C. Strong cytowany przez W1. Galewicza, Status..., s. 234.

24 J. Zaręba-Szczudlik, E. Romejko-Wolniewicz, A. Malinowska-Polubiec, S. Ahmed, A. Świetlik, K. Czajkowski, Analiza czynników ryzyka zgonów wewnatrzmacicznych płodów, Perinatologia, Neonatologia i Ginekologia 2009, t. 2, z 3, s. 203 i n., http://www.ptmp.com.pl/png/png2z3_2009/PNG23-6-Zarembaanaliza.pdf [dostęp 25.9.2017 r.]
} 


\section{MŁODY JURYSTA 2017/3}

związanych z przeszczepem oraz oświadczyć, że nie posiada informacji dotyczącej potencjalnych odbiorców. Gdy tkanka płodu pochodzi $z$ dokonanej aborcji, zgoda kobiety na przerwanie ciąży musi nastąpić wcześniej, niż zgoda na przekazanie tkanki martwego płodu do badań. Dodatkowo wymagane jest oświadczenie osoby odpowiedzialnej za badania, że ma świadomość skąd pochodzi ta tkanka oraz na jaki cel została przeznaczona. Z przekazaniem tkanki nie może wiązać się żadna korzyść majątkowa. Obowiązuje także bezwzględny warunek nieznajomości tożsamości biorców. Regulacje nie dotyczą możliwości wykorzystywania komórek z martwych płodów ${ }^{25}$.

Choć opozycjoniści wykorzystywania gonad martwych płodów twierdzą, że to przestarzała metoda badań i obecnie można zastosować lepsze alternatywy, to słusznie wskazują zwolennicy, że tkanka płodu w razie jej niewykorzystania zostanie zniszczona. Tymczasem nadal pewnych badań nie można przeprowadzić w inny sposób, niż na podstawie tkanek płodu ludzkiego, a dotychczasowe prace badawcze doprowadziły do znacznego rozwoju medycyny. Niektórzy uważają, że atakowanie badań z wykorzystaniem płodów, to próba ograniczenia bądź zlikwidowania dostępu do aborcji ${ }^{26}$.

Wytypowanie matki jako jedynego decydenta słusznie budzi wątpliwości W szczególności w przypadku, gdy pozyskanie tkanki martwego płodu było wynikiem dokonanej aborcji. Trafnym rozwiązaniem jest uprzednie wyrażenie woli dokonania zabiegu przerwania ciąży, a dopiero w późniejszym czasie, otrzymanie zgody na przekazanie tkanek płodu do badań. W większości przypadków, tkanki te wykorzystywane są do badań chorób nieuleczalnych, jak HIV/AIDS, Parkinson bądź Alzheimer. Słusznie zauważył Lishan Su, że choć wykorzystywanie tego typu tkanek nie jest łatwą decyzją, obecnie nie ma innego wyjścia jak dalsze badania, jeśli chcemy ocalić ludzkie życie.

\section{Podsumowanie}

Wyrażanie świadomej zgody na wykorzystywanie gonad martwych płodów jest kontrowersyjnym problemem. Niewątpliwie wpływ na taki stan rzeczy wynika $\mathrm{z}$ przeprowadzanych $\mathrm{w}$ przeszłości eksperymentów medycznych (m.in. podczas II Wojny Światowej), podczas których doszło do licznych nadużyć. Często to religia nakazuje, by traktować zarodki oraz płody jako żyjące istoty, którym przysługuje pełny katalog

\footnotetext{
25 University of Wisconsin, Use of Human Fetal Tissue in Research, https://kb.wisc.edu/gradsch/page.php?id=28997 [dostęp 25.9.2017 r.]

26 M. Wadman, The truth about fetal tissue research, Nature 2015, nr 528 (7581), s. 178-181, $\mathrm{http} / /$ www.nature.com/news/the-truth-about-fetal-tissue-research-1.18960 [dostęp 25.9.2017 r.]
} 
ochronny i jest to przekonanie, z którym nie da się spierać. Wykorzystanie martwych płodów można jednak rozważać na tle medycznym i prawnym, a więc również etycznym. Choć w przypadku martwych płodów kwestia poświęcenia ich na rzecz badań wydaje się rozwiązana, problem dotyczy pozyskania komórek w kontekście sposobu obumarcia płodu, zwłaszcza aborcji. Powstaje pytanie, czy te same argumenty przemawiają za bądź przeciwko wykorzystaniu komórek $\mathrm{z}$ martwych płodów w razie poronień naturalnych i martwych urodzeń? Czy problematyka przerywania ciąży przez kobietę powinna zamykać dyskusję dotyczącą wykorzystywania martwych płodów? Ponadto, skoro wskazuje się, że należy je traktować jako osoby żyjące, to czy w takim przypadku, sfera decyzyjna nie jest przenoszona na najbliższe osoby żyjące, tj. matkę oraz ojca?

Niezwykle interesujące rozwiązanie znajduje się w prawie francuskim oraz brytyjskim a dotyczy to zgody na przekazywanie zamrożonych embrionów. W obu wskazanych regulacjach to rodzice posiadają prawo do podejmowania decyzji o losie embrionów. Warto rozważyć to rozwiązanie także na tle wykorzystywania martwych gonad, wznosząc się w dyskusji ponad kwestie światopoglądowe, a kierując się względami rozwoju medycyny, inżynierii genetycznej, a także potrzeby zmian prawnych.

\section{The issue of consent of using human fetal tissues}

\section{Summary}

The article concerns the issue of consent of using human fetal tissues and stem cells. The problem is significant because of the possibility of using fetal tissues in the treatment of many diseases, but it's also controversial because of the disagreement over the termination of pregnancy by women and the way that the tissues are obtained. Also the needed consent for participant in the medical experiment is problematic.

\section{Maria Grotowska}

Absolwentka prawa na Wydziale Prawa i Administracji Uniwersytetu Kardynała Stefana Wyszyńskiego w Warszawie. Jej zainteresowania koncentrują się wokół prawa karnego i medycznego. 